\title{
Aplikasi Client Server Berbasis Android pada Barbershop The Barbega Menggunakan Model Multi Channel - Single Phase
}

\author{
Yurindra $^{[1]^{*}}$, Ari Amir Alkodri ${ }^{[2]}$, Anisah $^{[3]}$, Supardi $^{[4]}$ \\ Program Studi Teknik Informatika ${ }^{[1],[2]}$, Program Studi Sistem informasi ${ }^{[3],[4]}$ \\ STMIK Atma Luhur, Pangkalpinang, Bangka belitung \\ yurindramail@gmail.com ${ }^{[1]}$, arie_a3@atmaluhur.ac.id ${ }^{[2]}$, anisah@atmaluhur.ac.id ${ }^{[3]}$, supardi@atmaluhur.ac.id $\mathrm{id}^{[4]}$
}

\begin{abstract}
A common problem that is often faced by almost most Barbershop is in terms of serving customer queues, for barbershops who have many customers and have many service chairs, then of course a good customer queue service management concept is needed as well. One of the concepts of queuing services for customers is how queue information can reach customers without queuing at the location. For this reason, a queue service concept for customers is needed based on Android. Android is preferred because almost all smartphone users are currently based on Android. The application will be built based on the concept of client server so that the queue service will occur in real time. The Queuing model used is Multi Channel Single Phase, because in the queue at barbershop there will only be one stage of the process, but it requires a lot of queue flow. This can be seen in the structure of the development diagram. By using an Android-based application based on a single phase multi channel model that will be built it is ensured that customers will find it helpful, without having to spend time in a queue customers can order queues and see queues in real time so they can rush to barbershop when it is close to the queue
\end{abstract}

Keywords- queue, client server, multichannelingphase, barbershop, customer service

\begin{abstract}
Abstrak - Permasalahan umum yang sering dihadapi oleh hampir kebanyakan Barbershop adalah dalam hal melayani antrian pelanggan, bagi barbershop yang memiliki pelanggan yang banyak dan memiliki kursi layanan yang banyak pula , maka tentunya dibutuhkan sebuah konsep manajemen pelayanan antrian pelanggan yang baik pula. Salahsatu konsep pelayanan antrian bagi pelanggan adalah bagaimana informasi antrian bisa sampai kepada pelanggan tanpa adanya antrian di lokasi. Untuk itu dibutuhkan sebuah konsep pelayanan antrian bagi pelanggan yang dibangun berbasis Android. Pilihan terhadap android karena hampir seluruh pengguna smartphone saat ini berbasis android. Aplikasi akan dibangun berdasarkan konsep client server sehingga layanan antrian akan terjadi secara real time . Model Antrian yang digunakan adalah Multi Channel Single Phase, karena dalam antrian pada barbershop hanya akan ada satu tahapan proses saja, namun membutuhkan banyak alur antrian. Hal tersebut dapat terlihat pada struktur proses diagram pengembangan . Dengan menggunakan aplikasi berbasis android berdasar model multi channel single phase yang akan dibangun ini maka dipastikan bahwa pelanggan akan sangat merasa
\end{abstract}

terbantu, tanpa harus manghabiskan waktu dalam antrian pelanggan dapat memesan antrian dan melihat antrian secara real time sehingga dapat bergegas menuju barbershop bila sudah dekat dengan antrian.

Kata Kunci-antrian, client server, multichanelsinglephase, barbershop, layananpelanggan

\section{PENDAHULUAN}

Perkembangan teknologi saat ini menjadikan masyarakat berfikir dan hidup lebih praktis, dalam revolusi 4.0 yang berbasis "Internet think" [1] masyarakat saat ini tidak dapat melepaskan diri dari smartphone (ponsel pintar). Hampir semua kegiatan sehari-hari menggunakan smartphone untuk membantu mempermudah kegiatan sehari hari. Seperti melakukan komunikasi, transaksi keuangan, pembelanjaan kebutuhan sehari hari, bahkan sampai pengaturan jadwal kegiatan. Hampir semua orang menuntut pelayanan publik untuk semakin efektif dan efisien ketika berbicara tentang pelayanan. Dalam hal ini termasuk kebutuhan bisnis yang didalamnya adalah kebutuhan akan pelayanan dari berlangganan Barbershop, Barbershop merupakan tempat dimana para pria untuk merapikan rambutnya agar tetap terlihat rapi dan bergaya. Bisnis barbershop ini sudah banyak di kota maupun pedesaan karena barbershop sudah menjadi kebutuhan pria maupun wanita untuk menjaga kerapian rambutnya .

Sistem antrian dapat dijumpai pada semua aspek kehidupan terutama dalam industri jasa, Ada 4 model yang dikenal dalam antrian yaitu antrian dengan satu jalur dan satu tahap (Single Channel, Single Phase), antrian dengan satu jalur, dan banyak tahapan (Single Channel, Multi Phase), antrian dengan banyak Jalur dan satu Tahapan (Multi Channel, Single Phase), antrian dengan banyak jalur dan banyak tahapan (Multi Channel, Multi Phase) [3]

Permasalahan mulai timbul ketika Pelanggan yang datang harus menunggu sangat lama dalam antrian, seperti yang terjadi pada Barbershop Barbega, bahwa pelanggan dalam antrian bisa mencapai 30 orang dalam satu waktu dengan kepentingan yang berbeda, sedangkan kursi perawatan yang disediakan hanya 8 saja. Beberapa pelanggan memilih pulang bila melihat penuhnya antrian. Pelanggan yang lain ada yang 
memilih pindah ke barbershop lain . ketidaknyamanan dalam menunggu antrian menjadi penyebab dari semua ini.

Untuk mengatasi hal tersebut maka dibangun sebuah aplikasi berbasis android yang membuat pelanggan dapat mendaftarkan antrian dan melihat progress antrian mereka dari rumah menggunakan aplikasi berbasis android yang di install dalam smartphone mereka. Model yang digunakan menggunakan multi channel single phase. Single Phase karena karena hanya ada satu fase atau satu proses tunggal dalam antrian, yaitu setelah antrian dilakukan langsung dieksekusi tanpa ada tahapan lain yang harus dilakukan . Multi Channel menjelaskan bahwa saluran atau kanal antrian dibutuhkan banyak, Barbega sediri memiliki 8 kanal atau saluran pelayanan berupa 8 kursi perawatan.

Terdapat pula beberapa penelitian terdahulu yang dianggap relevan dengan penelitian ini :

Hendra Cipta, Rangga Gelar Guntara pada tahun 2017 mengembangkan Pembangunan Perangkat Lunak Online Booking Barbershop di Bandung namun Menggunakan Teknologi Mobile Global Positioning System dan Web Service Pada Platform Android.[2] , Penelitian M. Safril Bahar, Mans Lumiu Mananohas, Chriestie E. J. C. Montolalu pada tahun 2018 masih sama yaitu mengenai Model Sistem Antrian namun dengan Menggunakan Pola Kedatangan dan Pola Pelayanan Pemohon SIM di Satuan Penyelenggaraan Adminstrasi SIM Resort Kepolisian Manado[3]. Penelitian Swono Sibagariang pada tahun 2016 mengenai Penerapan Web Service Pada Perpustakaan Berbasis Android[4] dalam penelitian ini diambil penggunaan web sevice sebagai acuan pembuatan server pada aplikasi barbershop . Penelitian Efmi Maiyana pada tahun 2018 mengenai Pemanfaatan Android Dalam Perancangan Aplikasi Kumpulan Doa[8] juga diambil sebagai acuan dalam teknik client server yang digunakan. Penelitian Suendri pada tahun 2018 mengenai Implementasi Diagram UML (Unified Modelling Language) Pada Perancangan Sistem Informasi Remunerasi Dosen Dengan Database Oracle[9]. Penelitian Ari Amir, pada tahun 2014 mengenai aplikasi pemesanan berbasis andorid dengan client server dalam jurnal sisfokom [10] , penelitian ini mirip dalam konsep namun tidak menjelaskan model MCSP. Hidayat dan ashari pada tahun 2013, melakukan penelitian serupa ( mirip dengan MCSP ) dengan studi kasus pada antian pelayanan di puskesmas dan rumah sakit.[5], berikutnya Surahman pada tahun 2017 , membuat aplikasi mobile berbasis android, dengan memanfaatkan sistem antrian Multi channel single Phase pada antrian Driver online [7]

Berdasarkan uraian pada bagian pendahuluan yang telah dijelaskan, maka permasalahan yang akan dikaji dalam penelitian ini dapat dirumuskan bahwa pelanggan barbershop cukup kerepotan hanya untuk datang mengambil nomor antrian dan pelanggan barbershop harus menunggu lama dalam antrian untuk mendapatkan pelayanan.

Sehingga untuk itu diperoleh tujuan dan manfaat dalam pengembangan aplikasi sistem antrian Barbershop The Barberga ini adalah bahwa aplikasi ini diharapkan mampu meningkatkan pelayanan terhadap pelanggan dalam hal membantu pelanggan untuk mampu memesan antrian dari rumah saja, disamping itu aplikasi ini diharapkan mampu membantu pelanggan untuk memantau progress antrian secara realtime.

\section{METODOLOGI PENELITIAN}

Metodologi penelitian dalam hal ini menjelaskan beberapa tahapan penelitian adalah sebagai berikut :

Metode pengembangan yang digunakan adalah menggunakan metode berorientasi objek, dengan menggunakan model Pengembangan perangkat lunak Prototype melalui pendekatan model Multi Channel Single Phase. Model Prototype yang digunakan dalam penelitian ini menggunakan tahapan sebagai berikut :

\section{A. Perencanaan}

Pada tahapan perencanaan kegiatan yang dilakukan adalah kegiatan persiapan pra penelitian dengan pengumpulan data di barbershop menggunakan metode observasi, penilaian atau studi kelayakan baik kelayakan operasional maupun kelayakan teknologi.

\section{B. Analisis}

Analisis sistem dilakukan untuk memberikan arahan dan menentukan tahapan pada problem statement yaitu
1. Penyelesaian masalah
2. Identifikasi kebutuhan
3. Analisis kebutuhan
4. Analisis kebutuhan Perangkat keras
5. Analisis sistem berjalan.
6. Analisis Kelayakan Sistem

\section{Perancangan Sistem}

Perancangan Sistem adalah merancang sistem secara rinci berdasarkan hasil analisis sistem yang ada, sehingga menghasilkan model baru yang diusulkan. Perancangan sistem dilakukan dengan tahap sebagai berikut:

\section{Perancangan sistem kerja}

Pada tahap ini menjelaskaan rancangan alur proses kerja baik yang sedang berjalan maupun yang akan dibangun digambarkan melalui Diagram activity.

2. Perancangan Perangkat lunak

Dalam perancangan perangkat lunak menggunakan Use case, Sequence dan juga menggunakan Class diagram untuk menjelaskan rancangan database yang akan digunakan.

3. Rancangan Layar.

Rancangan layar di perlukan untuk merepresentasikan bentuk tampilan sebelum di implementasikan..

\section{Hasil dan Implementasi}

Pada tahap ini adalah proses memaparkan hasil-hasil rancangan dalam bentuk tampilan layar program.

\section{E. Hasil Rancangan Sesuai Metodologi Penelitian}

Sesuai dengan Metodologi penelitian yang telah disusun maka dapat dilihat analisis dan rancangan umum dari pengembangan aplikasi ini.

\section{Tahapan proses yang terjadi secara manual}


Berdasarkan analisis masalah yang telah dijabarkan sebelumnya, prosedur pemesanan antrian manual di the barberga yang dilakukan di barbershop dapat dilihat pada gambar berikut ini :

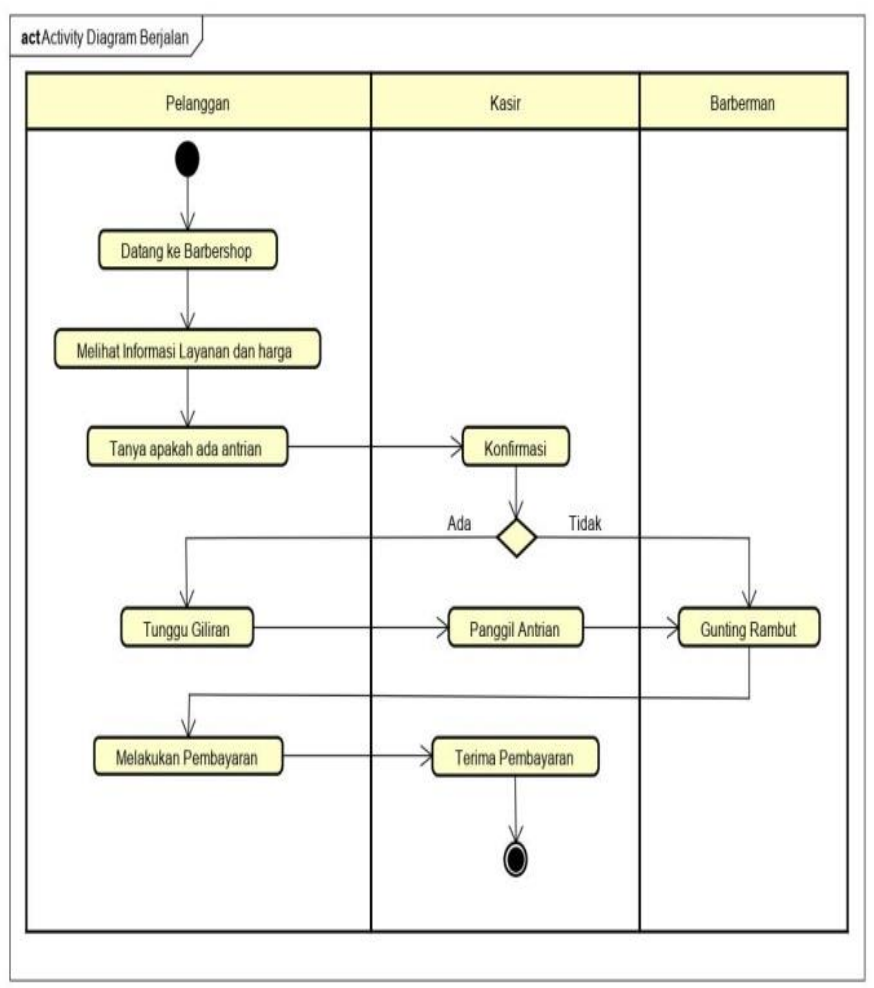

Gambar 1. Prosedur antrian manual

Keterangan gambar :

- Pelanggan datang langsung ke Barbershop.

- Melihat informasi layanan dan harga layanan pada poster.

- Melihat apakah ada tukang cukur yang sedang tidak melayani pelanggan.

- Jika ada Pelanggan yang sedang cukur, pelanggan yang baru datang menunggu giliran gunting rambut.

- Jika tidak ada pelanggan langsung dapat layanan gunting rambut.

- Pelanggan memberikan informasi hairstyle apa yang diinginkan.

- Barberman menerima informasi dan melayani permintaan pelanggan.

- Setelah selesai gunting rambut, pelangggan bisa langsung melakukan pembayaran ke kasir.

2. Proses tahapan perancangan perangkat lunak

Dalam perancangan perangkat lunak, digunakan beberapa diagram seperti yang terlihat pada gambar dibawah ini :

a) Diagram Usecase



Gambar 2. Diagram usecase rancangan menu utama

Keterangan gambar :

- Pelanggan dapat memilih menu mendaftar pada antrian.

- Pelanggan dapat melihat progress antrian.

- Pelanggan dapat melihat fasilitas product layanan yang ditawarakan.

- Pelanggan dapat memberikan saran kepada Admin

- Selain itu admin dapat melakukan update, tambah dan delete terhadap layanan product dan antrian.

b) Diagram Activity



Gambar 3. Diagram activity daftar antrian

Keterangan gambar :

Gambar di atas menunjukkan bahwa,

- Pelanggan membuka aplikasi, kemudian

- Sistem menampilkan menu utama.

- Untuk melakukan daftar antrian, pelanggan membuka menu daftar.

- Sistem menampilkan form daftar yang harus dilengkapi oleh pelanggan berupa nama.

- Setelah melengkapi form yang dibutuhkan, klik daftar. Maka,

- System akan menampilkan pesan berupa nomor 
antrian kepada pelanggan untuk mengikuti prosedur.

c) Diagram Sequence

Dibawah ini merupakan sequence diagram pelanggan yang diusulkan, penulis menggambarkan sebagai berikut :

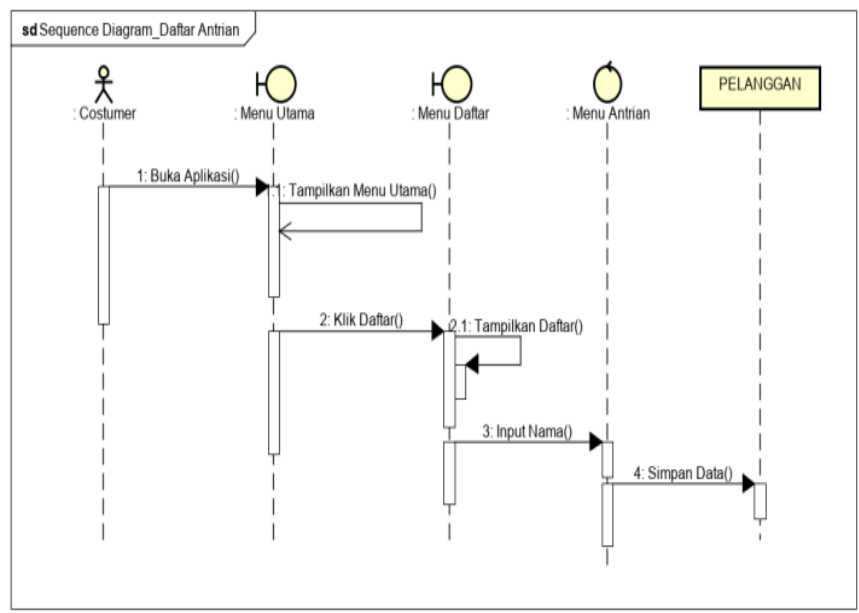

Gambar 4. Sequence Diagram Daftar Antrian

Gambar diatas merupakan Sequence Diagram daftar antrian yang menggambarkan proses yang sedang terjadi dalam daftar antrian. Prosesnya dimulai dengan user masuk ke dalam form daftar terlebih dahulu, kemudian selanjutnya user dapat giliran antrian dengan memasukkan nama untuk dapat masuk ke dalam sistem. Data akan disimpan di database Pelanggan.

\section{d) Diagram Class}

Dibawah ini merupakan class diagram yang dibangun, yang digambarkan sebagai berikut :

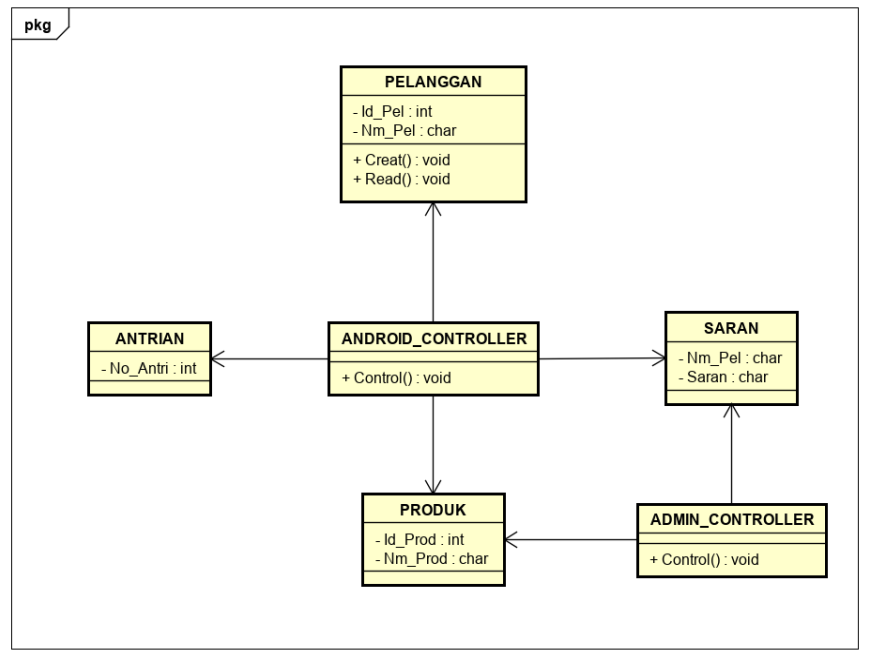

Gambar 5. Class Diagram

Keterangan gambar :

Class diagram diatas menunjukan bahwa aplikasi ini terdiri dari 6 tabel yang saling berkaitan yaitu tabel Pelanggan,Tabel Antrian, tabel Control android, Tabel Product, Tabel Saran, Tabel admin. e) Rancangan Layar

Berikut ini adalah rancangan layar bagi penerapan aplikasi barbershop :

1) Rancangan layar menu Home

Dapat dilihat pada gambar 6 bahwa pada menu 'home' terdapat 2 digit angka yang bersebelahan, angka disebelah kiri menunjukan antrian yang saat ini sedang berjalan, sedangkan angka yang disebelah kanan menunjukan nomor antrian kita saat ini, dibawah nomor antrian terdapat button daftar antrian untuk melakukan daftar pada antrian. Button paling bawah menunjukan 3 button yaitu button antrian, product barbershop dan saran.



Gambar 6. Rancangan Layar Menu Home

2) Rancangan layar menu Lihat Antrian

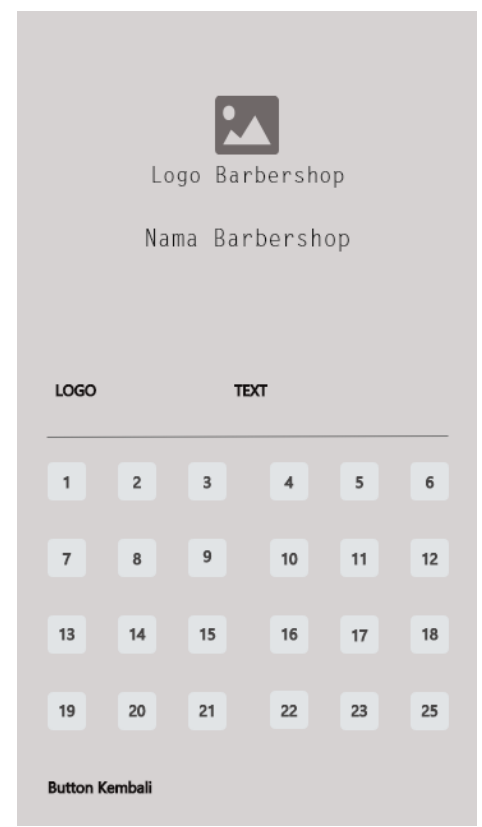

Gambar 7. Rancangan layar menu lihat antrian 
Pada gambar 7 dibawah ini dapat dilihat rancangan daftar antrian yang sedang berjalan secara deret angka, disitu juga dapat dilihat nomor antrian kita berada.

\section{Rancangan Multi Channel Single Phase pada aplikasi}

Pelaksanaan penelitian dilakukan dengan metode Multi channel-single pass seperti pada gambar berikut ini :

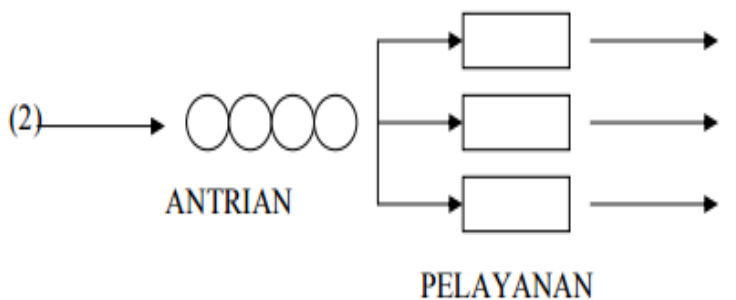

Gambar 8. Konsep Multi channel-single pass

Model ini sangat dianjurkan dalam konsep antrian pada barbershop. Konsep model ini adalah bagi model antrian yang memiliki banyak kanal atau saluran atau pintu pelayanan yang banyak, namun tidak memiliki tahapan yang berbelit belit layaknya birokrasi. Dalam model ini setiap pelanggan yang mendapat panggilan antri akan langsung dieksekusi pada satu tahapan lalu selesai, tidak dieksekusi dengan tahapan proses yang panjang [3]

Konsep Multi Channel Single Phase dapat diperjelas pada diagram terstruktur sebagai berikut :



Gambar 9. Penerapan MCSP pada Aplikasi

Dapat dilihat pada gambar tersebut bahwa support aplikasi ini dibangun atas dasar banyak pelanggan yang berhubungan dengan banyak kanal ( seat )/( konsep Multi Channel ), lalu hanya pada satu tahapan saja setelah antrian terjadi kegiatan ( potong rambut ) di lakukan / eksekusi lalu membayar dan selesai, tanpa ada tahapan proses lainnya (konsep Single Phase ) . Struktur menu dan rancangan pada aplikasi yang dipersiapkan memungkinkan konsep ini dapat berjalan baik diatas platform android berbasis client server yang akan dibangun.

\section{HASIL DAN PEMBAHASAN}

\section{A. Tampilan Layar}

Dibawah ini merupakan tampilan layar yang diusulkan, penulis menggambarkan sebagai berikut

\section{1) Tampilan Layar Welcome}

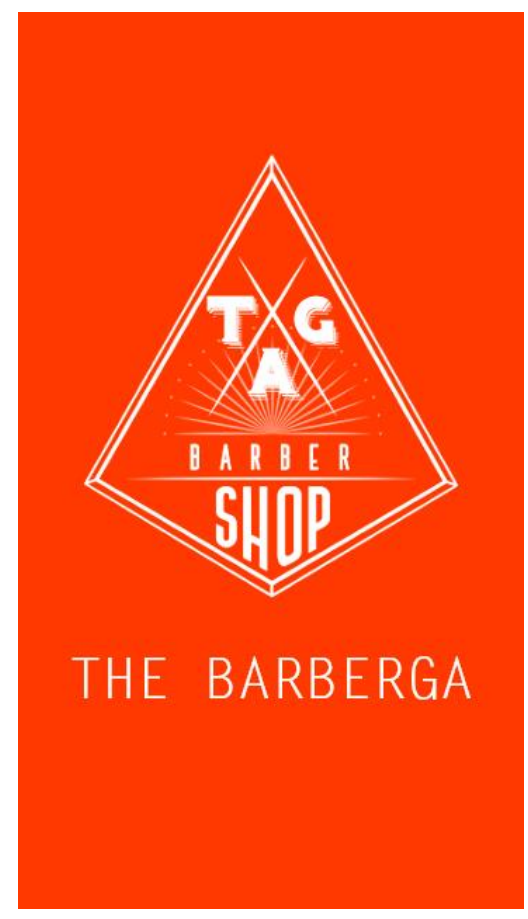

Gambar 10. Tampilan layar Welcome

Gambar 10 tersebut menunjukan tampilan awal dalam menu pembuka pada aplikasi setelah di bangun, dilengkapi dengan simbol dari Barbershop Barbega.

\section{2) Tampilan Layar Home}

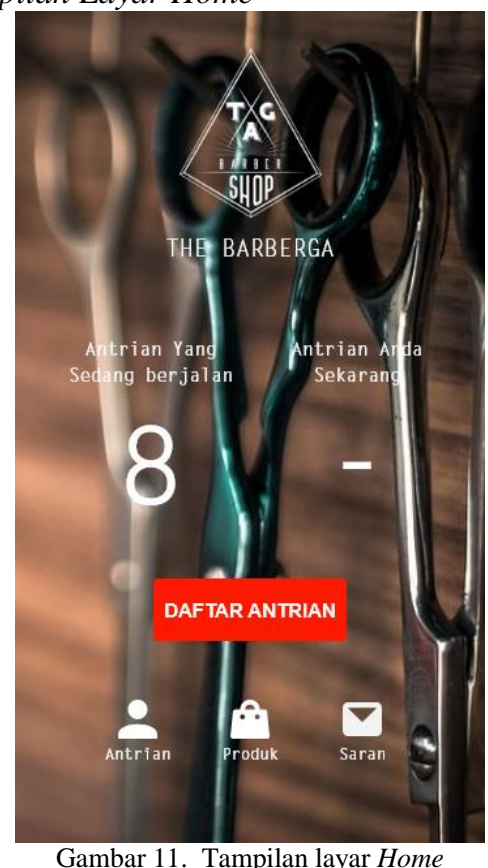

Gambar 11. Tampilan layar Home 
Pada gambar 11 Tampilan layar home memperlihatkan nomor antrian yang sedang berjalan, serta button untuk mendapatkan daftar antrian yang dibutuhkan .Pada button yang ada dibawah disediakan menu untuk melhat daftar antrian yang sedang berjalan, Produk layanan dan kotak saran.

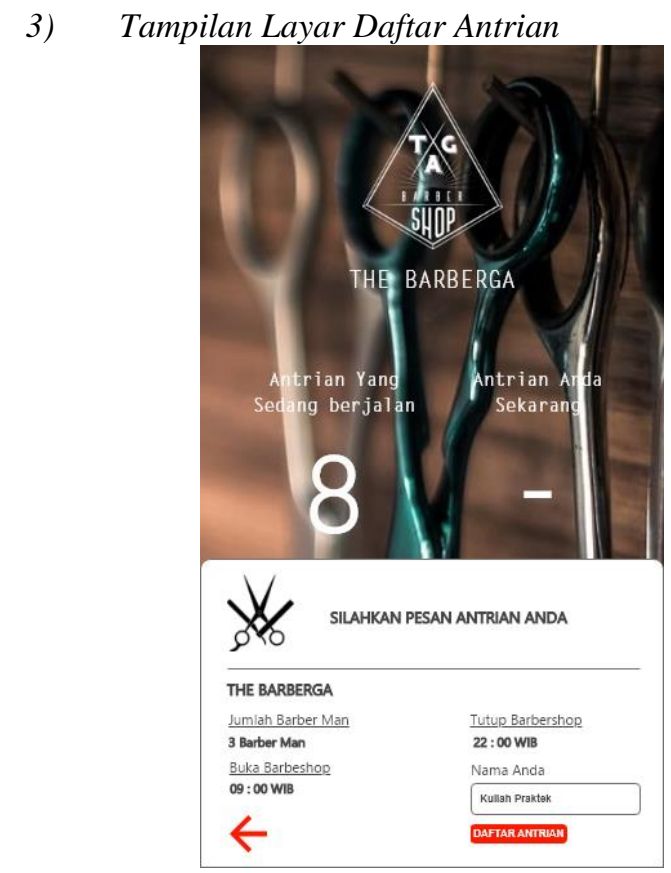

Gambar 12. Tampilan layar Daftar Antrian

Pada gambar 12 dijelaskan bahwa menu untuk memesan atau mendaftar antrian dilengkapi dengan informasi jumlah barberman yang tersedia serta jadwal tutup barbershop .

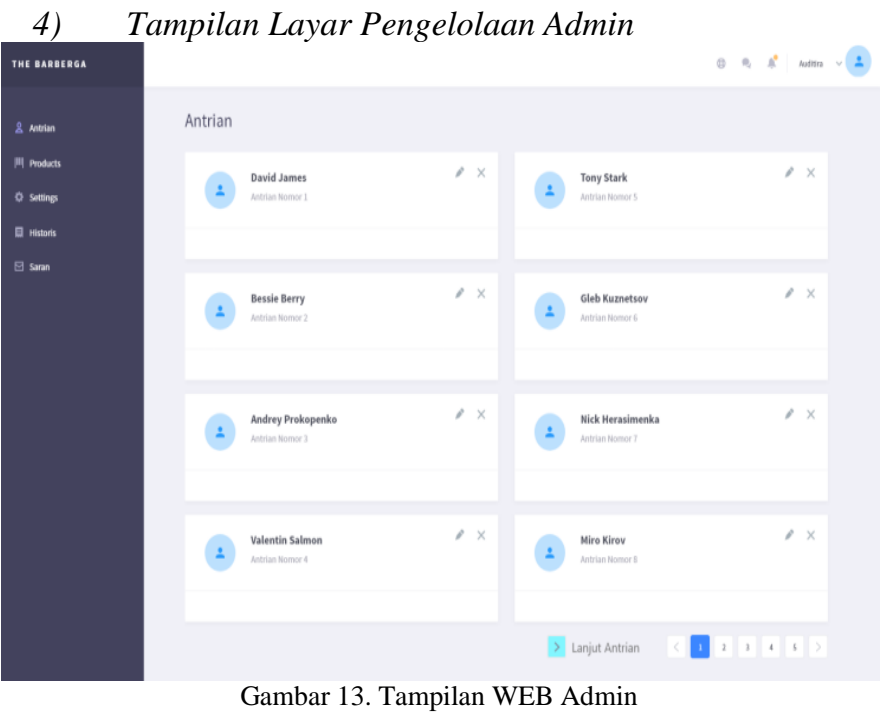

Gambar 13 menunjukan tampilan halaman pengelolaan bagi admin dari sisi server, admin dapat memantau seluruh transaksi pesan antrian, batal maupun memantau kegiatan barberman yang bertugas. Ada 5 fungsi utama bagi admin dalam halaman ini yaitu menu setting, Historis pengunjung, Kontrol Antrian, Saran dan pengelolaan produk . Disamping itu bila dibutuhkan lebih dari satu admin, maka nama admin yang bertugas akan terekam dalam halaman ini sesuai historis.

\section{PENUTUP}

Dari hasil penelitian yang dilakukan dapat ditarik kesimpulan bahwa pada aplikasi dengan model antrian berbasis android menggunakan Multi Channel single phase ini mampu mempermudah pelanggan untuk melakukan pemesanan antrian secara online dan real time menggunakan smartphone mereka tanpa harus datang terlebih dahulu di barbershop "the barberga" Pangkalpinang. Selain itu dengan menggunaan apikasi ini pelanggan dapat memperkirakan kapan harus datang ke tempat pelayanan dengan melihat progres daftar nomor antrian pada aplikasi. Untuk menyempurnakan aplikasi ini disarankan untuk dapat menggunakan metode time event atau time boxing untuk dapat memberikan batasan pada pelanggan sesuai dengan waktu yang telah ditentukan. Hal tersebut berguna bagi pihak pengelola untuk mengatasi permasalahan bagi pelanggan yang sudah memesan namun tidak datang. Walaupun telah disediakan menu pembatalan, namun kadangkala pelanggan malas atau lupa untuk meng'klik' menu batal pesan, sehingga dapat diantisipasi dengan metode time event atau time boxing.

\section{DAFTAR PUSTAKA}

[1] Kevin Ashton, 2009 “ That' Internet of Things 'thing “ RFIDJournals

[2] H. Cipta and R. G. Guntara, 2017 "Pembangunan Perangkat Lunak Online Booking Barbershop di Bandung Menggunakan Teknologi Mobile Global Positioning System dan Web Service Pada Platform Android," Tugas Akhir,.

[3] S. Bahar, M. L. Mananohas, and C. Montolalu, 2018 "Model Sistem Antrian dengan Menggunakan Pola Kedatangan dan Pola Pelayanan Pemohon SIM di Satuan Penyelenggaraan Adminstrasi SIM Resort Kepolisian Manado," d'CARTESIAN, vol. 7, no. 1, p. 15,

[4] S. Sibagariang, 2016 "Penerapan Web Service Pada Perpustakaan Berbasis Android," vol. 1, no. 1, pp. 28-32,.

[5] H. Services, 2013 "Penerapan Teknologi Web Service Untuk Integrasi Layanan Puskesmas dan Rumah Sakit,” Bimipa, vol. 23, no. 1, pp. 6477, .

[6] H. Deviana, 2011 "Penerapan XML Web Service Pada Sistem Distribusi Barang," J. Generic, vol. 6, no. 2, pp. 61-70,.

[7] S. Surahman and E. B. Setiawan, 2017 “Aplikasi Mobile Driver Online Berbasis Android Untuk Perusahaan Rental Kendaraan," J. Ultim. InfoSys, vol. 8, no. 1, pp. 35-42,.

[8] E. Maiyana, 2018 "Pemanfaatan Android Dalam Perancangan Aplikasi Kumpulan Doa,” J. Sains dan Inform., vol. 4, no. 1, pp. 54-65,

[9] Suendri, 2018 "Implementasi Diagram UML (Unified Modelling Language) Pada Perancangan Sistem (Studi Kasus : UIN Sumatera Utara Medan)," J. Ilmu Komput. dan Inform., vol. 3, no. 1, pp. 1-9,.

[10] L. Candra and A. A. Alkodri, 2014 "Aplikasi Pemesanan Makanan Pada Bangka Original Cafe Berbasis Client Server Dengan Platform Android," J. Sisfokom (Sistem Inf. dan Komputer), vol. 3, no. 2, p. 34. 